Vol. 21 (2017), pp. 334-354

ISSNe: 2530-6324 || ISSN: 1138-039X

DOI: https://doi.org/10.17979/afdudc.2017.21.0.3294

\title{
O MECANISMO DE RESOLUCIÓN DE CONTROVERSIAS NO ACTI
}

\author{
DAVID SOTO DÍAZ \\ Investigador de Dereito Procesual \\ Gañador do VII Premio Lois Tobío de Investigación Xurídica en Lingua Galega (modalidade \\ de graduados) \\ Universidade da Coruña
}

Resumo: A arbitraxe entre Estados e investidores particulares doutros Estados, coñecida polas súas siglas en inglés, ISDS, ten sido obxecto de críticas ao longo dos últimos anos, polas malas consecuencias que ten tido especialmente nos países en vías de desenvolvemento. O Acordo Transatlántico para o Comercio e o Investimento, máis coñecido polas súas siglas en inglés TTIP, prevía incorporar, nun primeiro momento este mecanismo de arbitraxe. Máis tarde debido á oposición popular ao Tratado, a Comisión Europea puxo sobre a mesa a posibilidade de establecer un Tribunal Permanente. O obxectivo deste traballo é analizar o mecanismo de acción da arbitraxe ISDS e do novo Tribunal proposto pola Comisión Europea.

Palabras clave: arbitraxe de investimentos, tratados multilaterais de protección dos investimentos, CIADI, Acordo Transatlántico de Comercio e Investimento.

Abstract: Investor-State dispute settlement, known as ISDS, has been subject of critique over the past few years because of the disturbing consequences it has provoked in the developing countries. In a very first moment, the Transatlantic Trade and Investment Partnership, known as TTIP, foresaw the inclusion of an ISDS clause. The contestation to this measure raised the possibility of establishing a Permanent Court. The objective of this research is to analyse the mechanism of action of ISDS and of the new Court proposed by the European Commission.

Keywords: investment arbitration, multilateral investment treaty, ICSID, Transatlantic Trade and Investment Partnership. 
SUMARIO: I. INTRODUCIÓN. II. CARACTERÍSTICAS DA ARBITRAXE ISDS. III. AS CRÍTICAS AO ISDS. 1. Deficiencias constitucionais do ISDS. 2. O ISDS como instrumento de disuasión da autonomía democrática dos Estados. 3. Ámbitos concretos nos que o ISDS podería servir como bloqueo das políticas públicas dentro do Acordo para a Asociación Transatlántica do Comercio e o Investimento. IV. PRIMEIRO PROXECTO DE RESOLUCIÓN DE CONTROVERSIAS NO ATCI: O ISDS. V. SEGUNDO PROXECTO DE RESOLUCIÓN DE CONTROVERSIAS NO ATCI: O TRIBUNAL DE INVERSIÓNS. VI. CONCLUSIÓNS; VII. BIBLIOGRAFÍA

\section{INTRODUCIÓN}

O mecanismo ISDS ponse en marcha logo da ratificación dun Tratado Internacional polo que se protexen as expectativas financeiras dos inversores estranxeiros. Os Tratados internacionais teñen sido o instrumento clásico de protección dos investimentos estranxeiros, se ben, con anterioridade á expansión da arbitraxe, os inversores confiaban a defensa dos seus intereses aos corpos diplomáticos do seu país ${ }^{1}$ quen, eventualmente, podían solicitar a intervención armada no país receptor de investimentos ${ }^{23}$.

Porén, a mediados do século XIX xorden en América Latina, no campo do Dereito internacional público, dúas posturas doutrinais que apuntaban a impedir tal intervención armada. Por unha banda, a chamada doutrina Drago, ideada polo chanceler arxentino apelidado así, que aspiraba a prohibir a intervención armada dos Estados receptores de inversións por parte de terceiros Estados, co gallo de satisfacer as débedas das que fosen acredores os nacionais deses terceiros Estados ${ }^{4}$.

Por outra banda, a raíz da segunda intervención armada en México por parte das tropas francesas (1862-1867), o xurista rioplatense Carlos Calvo propuxo entender que as potencias internacionais, consonte o principio de integridade territorial, non debían inmiscirse nos asuntos políticos doutros Estados, mentres que, a modo de contrapartida, ningún Estado debería poder facer diferenzas entre nacionais e estranxeiros á hora de garantir o acceso á Administración de Xustiza, de tal xeito que, en caso de impagamento de débedas, os inversores estranxeiros debían acudir aos tribunais nacionais dos Estados receptores para que estes executasen con eficacia a débeda da que fosen acredores.

Esta proposta foi cristalizada na coñecida como cláusula Calvo, unha cláusula usualmente incluída nos contratos asinados con investidores estranxeiros. Porén, a

\footnotetext{
${ }^{1}$ DOLZER, R.; SCHREUER, C.; Principles of International Investment Law, Oxford, Oxford University Press, 2012, páx. 232

${ }^{2}$ GRANATO, L.; Protección del Inversor Extranjero en los Tratados Bilaterales de Inversión, Bos Aires, 2005; páxs. 4 e 5

${ }^{3}$ Así aconteceu, por exemplo, na coñecida como Guerra dos Pasteis, na que Francia interviu en México para esixir, entre outros asuntos, o pagamento das perdas que os cidadáns daquel país sufriran como consecuencia da revolución independentista

${ }^{4}$ DÍEZ DE VELASCO, M.; «Procedimientos de aplicación de las normas internacionales $(I) »$ en Instituciones de Derecho internacional público, Ed. Tecnos, $17^{\mathrm{a}}$ ed., Madrid, 2009; páx. 907
} 
xurisprudencia do Dereito internacional público tendeu a plasmar unha concepción da protección diplomática segundo a cal esta era entendida como un dereito propio do Estado $^{5}$, de xeito tal que calquera renuncia á mesma por parte dos súbditos carecería de valor ${ }^{6}$. Con isto, subsistía sempre a posibilidade de que as potencias, co obxectivo de brindar protección diplomática á súa cidadanía, puidesen recorrer incluso á intervención militar, deixando sen efecto a cláusula Calvo.

A día de hoxe, o problema que tentaban garantir as doutrinas Calvo e Drago subsiste; se ben os usos internacionais parecen desbotar a posibilidade do recurso á acción bélica. Neste escenario actual, pódense imaxinar dous tipos de conflitos no referente ás inversións estranxeiras. Por unha banda, os nados a partir de incumprimentos de contrato e, por outra, aqueles que teñen lugar a causa das políticas concretas das autoridades públicas do Estado receptor.

Dentro da primeira clase, débese diferenciar entre dous tipos de contrato: primeiro, os contratos entre particulares, isto é, do inversor con cidadáns ou empresas dos Estados receptores e, segundo, entre investidores estranxeiros e Administracións públicas. No primeiro suposto, de contratos entre particulares, o preito debe ser ventilado perante os tribunais do país receptor ${ }^{7}$. No segundo caso, isto é, de contratacións coas Administracións Públicas e, en caso de incumprimento de contrato, a orde contenciosoadministrativa - no caso do Estado español-, que forma parte da xurisdición ordinaria, entenderá do incumprimento ${ }^{8}$. Así, ao igual que no anterior caso, un xuíz independente, imparcial e predeterminado legalmente coñecerá e resolverá o asunto, aplicando as normas de Dereito de contratación administrativa que corresponda. En calquera caso, se por unha conduta imputábel aos órganos xurisdicionais, estes inadmitiran infundadamente a demanda presentada polo inversor, ou non entrasen a coñecer do fondo do asunto tendo a posibilidade de facelo, os particulares poderían presentar tamén recurso de amparo perante o $\mathrm{TC}^{9}$, para que obrigue aos órganos xudiciais a actuar conforme á Lei, tutelando os dereitos recoñecidos á empresa demandante.

Queda aínda outra posibilidade de conflito: a que nace da mudanza das políticas públicas ou dos cambios lexislativos. Nestes casos, en principio, os particulares non poden esixir unha indemnización ao Estado, que en realidade está exercitando a súa potestade gobernativa e/ou lexislativa. Porén, en caso de que o acto administrativo mediante o cal se pon en xogo unha nova política comercial, tributaria ou económica, atente contra o principio de igualdade e non discriminación, daquela as empresas afectadas poderán recorrer o acto administrativo discriminatorio perante a xurisdición contencioso-administrativa. E, en todo caso, perante o TC nun último termo.

\footnotetext{
${ }^{5}$ Dentro da arbitraxe de investimentos destaca o laudo do asunto North American Dredging Company of Texas c. Estados Unidos Mexicanos de 1926, perante a Convención de Reclamacións Xeral do Tratado de Bucareli, onde se razoaba que "non existe ninguna regra internacional que prohíba o Dereito soberano dunha nación a protexer aos seus cidadáns no estranxeiro fronte calquera limitación á que sexan sometidos" [Trad. Propia]

${ }^{6}$ DIEZ DE VELASCO, M.; Instituciones de Derecho internacional público... páxs. 905-906

${ }^{7}$ Para o caso español, vid. Arts. 50 e 51 Lei 1/2000, de Axuizamento Civil; así como, para o ámbito da UE, vid. Art. 4.1 apartados a), b), e) e f) e art. 4.2 do Regulamento (CE) 593/2008 do Parlamento Europeo e do Consello, sobre a lei aplicábel ás obrigas contractuais ("Roma I")

${ }^{8}$ Para o caso español, vid. Art. 2.b) da Lei 29/1998, pola que se regula a Xurisdición ContenciosoAdministrativa

${ }^{9}$ Para o caso español, vid. Art. 53.1 Constitución española
} 
Cómpre facer tamén unha breve referencia ao Sistema Xurisdicional da Unión Europea - de agora en adiante, SXUE. Dende a institución da Comunidade Europea do Carbón e o Aceiro, en 1951, creouse un órgano xurisdicional encargado de velar pola aplicación uniforme e a primacía do Dereito comunitario. Hoxe en día, o Tribunal de Xustiza da Unión Europea, herdeiro daquel primeiro tribunal, culmina a pirámide xudicial composta por todos e cada un dos órganos xudiciais do Estados membros ${ }^{10}$, sendo que, o TXUE funciona como un auténtico tribunal constitucional no que toca ao Dereito da Unión.

O Dereito da UE, pola súa banda, desprega unha serie de regulacións que atinxen a variadas competencias relacionadas coas inversións, regulando dende a unión alfandegueira, a política comercial común ou as normas de competencia mercantil onde exerce en exclusividade as súas competencias- ata o mercado interior ou a cohesión económica -onde as competencias son compartidas, é dicir, de regulación preferente pola UE. Acontece así que, en caso de incumprimento por parte dos Estados de algunha norma sobre Dereito comercial, as empresas inversoras estranxeiras poderían suscitar a actuación do TXUE, co gallo de aplicar as normas, de carácter marcadamente liberal, da UE, que gozan en todo caso de efecto directo -consonte ao establecido da STXUE no caso Van Gend en Loos e concordantes.

\section{CARACTERÍSTICAS DA ARBITRAXE ISDS}

O ISDS é un mecanismo de arbitraxe propio de determinados TPPIs e ten por obxectivo favorecer a aparición dun clima favorábel para as e os inversores, permitíndolles subtraerse á xurisdición dos tribunais do Estado receptor. Para BILLIET ${ }^{11}$, o ISDS diferénciase doutros sistemas de arbitraxe primeiro, polo marco legal aplicábel principalmente, Dereito internacional público-, segundo, pola competencia do tribunal que ten potestade para axuízar actos soberanos- e, terceiro, polas partes implicadas Estados e particulares nacionais doutros Estados.

Alén de máis, o ISDS non se fundamenta nas cláusulas arbitrais tradicionais, propias dos contratos de inversión nos que o consentimento para someterse a arbitraxe é dado pola empresa inversora e mais o Estado receptor. No caso do ISDS, a empresa pode dar comezo a un procedemento arbitral polo mero feito de ter o Estado receptor asinado o Tratado con anterioridade ${ }^{12}$. É dicir, a empresa non é parte do convenio arbitral, senón que se vale do feito de que o seu Estado de orixe teña asinado un tratado internacional co Estado receptor ${ }^{13}$.

\footnotetext{
${ }^{10}$ SARMIENTO, D.; Poder Judicial e integración europea. La construcción de un modelo jurisdiccional para la Unión; Ed. Thomsom Civitas, Madrid, 2004, páx. 38

${ }^{11}$ BILLIET, J.; International Investment Arbitration. A practical Handbook; Maklu; Amberes, 2016, páx. 30

${ }^{12}$ FERNÁNDEZ MASIÁ, E.; Tribunales nacionales, arbitraje internacional y protección de inversiones extranjeras, Ed. Marcial Pons, Madrid, 2008, páx. 22

${ }^{13}$ Hai que destacar que no caso das corporacións multinacionais, o criterio do Estado de orixe é tremendamente flexíbel, xa que logo, abondaría con mudar a residencia para mudar de Estado de orixe, como foi o caso da compañía canadense Lone Pine Resources, que mudou a súa domicilio aos Estados Unidos para poder plantexar unha arbitraxe ISDS contra Canadá ao abeiro do Tratado de Libre Comercio
} 
Isto último levou a afirmar que os Estados, no eido dos TPPIs, prestan un «consentimento avanzado» ${ }^{14}$, no sentido de que fan unha oferta aberta de someter a arbitraxe calquera controversia que puidera xurdir no futuro; sendo isto así, non sería ata o momento no que o investidor particular suscita o preito -é dicir, en que acepta a oferta aberta de arbitrar- que se constitúe un acordo de arbitraxe. Isto reduce sensibelmente a autonomía dos Estados receptores dos investimentos, posto que non teñen a posibilidade de decidir para o caso concreto, quedando vinculados pola sinatura dun Tratado aplicábel entre as partes. A tendencia actual nos TPPIs é permitir á empresa demandante elixir entre demandar ao Estado perante a xurisdición ordinaria ou recorrer á arbitraxe CIADI, ou incluso solicitar o establecemento dun tribunal arbitral ad hoc mediante a aplicación do Regulamento de Arbitraxe da CNUDMI.

O Convenio do CIADI ${ }^{15}$ prevé un modo de nomeamento de árbitros no que prima a autonomía das partes, se ben ofrece unha Listaxe de Árbitros propia da que poden botar man as partes implicadas. Unha vez constituído o Tribunal, este decidirá sobre os límites da súa competencia (art. 41. 1 Convenio CIADI), é dicir, establecerá por si propio - a falta de normas que o regulen- aqueles asuntos dos que vai poder coñecer, sempre que teñan relación co asunto principal. Isto foi visto como unha agresión ao dereito á tutela xudicial efectiva (o cal é un dereito recoñecido na meirande parte das Constitucións estatais) por algún autor, como CAPIEL ${ }^{16}$, pois impediría que a parte perxudicada por esa autoatribución de competencia do tribunal puidera someter á xurisdición ordinaria os asuntos que atrae para si o tribunal de arbitraxe.

Por outra banda, o órgano controlador do laudo é o propio CIADI, a través dunha comisión formada por árbitros pertencentes á súa lista constituída para o caso concreto. Este control é máis limitado do que o previsto no Dereito estatal, pois a revisión só se pode instar consonte a certas irregularidades de carácter formal ${ }^{17}$ : constitución incorrecta do Tribunal, extralimitación nas súas funcións ou corrupción dalgún membro do mesmo; quebrantamento grave dunha norma de procedemento ou falta de motivación do laudo (art. 52 Convenio CIADI); excluíndo o control sobre cuestións de fondo, é dicir, o control que confirmaría ou non a observación por parte dos árbitros do ordenamento xurídico aplicábel. Daquela, un laudo do CIADI podería obrigar a un Estado a actuar contra o seu propio Dereito, por exemplo, se o obrigase a indemnizar en concepto de expropiación indirecta a unha empresa tabaqueira polas perdas económicas sufridas a causa do aumento dos impostos que debe pagar a cidadanía polo consumo.

de América do Norte - de agora en adiante, TLCAN-, co gallo de solicitar a remoción da moratoria da fracturación hidráulica -tamén coñecida como fracking- decidida polas autoridades do Quebec

${ }^{14}$ FERNÁNDEZ MASIÁ, E. (2008); páx. 24

${ }^{15}$ Segundo á introdución ao Convenio CIADI, a función deste organismo é «proporcionar servizos para a conciliación e a arbitraxe de diferenzas en materia de investimentos entre Estados Contratantes e nacionais doutros Estados Contratantes». En calquera caso, o CIADI forma parte do conglomerado do Banco Mundial, unha organización internacional creada en 1946 e cuxa natureza está a medio camiño entre a de institución especializada da ONU e a de Organización Internacional autónoma. En calquera caso, para poder preitear ao abeiro do Convenio CIADI, os Estados implicados deben ser parte do Convenio. A pesar disto, desde o 2006, o Centro emitiu o Regulamento do Mecanismo Complementario, que serve para regular os procedementos arbitrais entre Estados non membros da CIADI, salvando así o bloqueo que ocasionaba a situación anterior

${ }^{16}$ Vid. CAPIEL, L.; «El principio Kompetenz-Kompetenz en España» en Revista del Club español de Arbitraje, núm. 8/2010, páx. 100

${ }^{17}$ O propio CIADI ten negado o carácter de "recurso de apelación" que este instrumento de impugnación podería ter 
Ademais do CIADI, moitos TPPIs recollen a posibilidade para as empresas multinacionais cuxo Estado de orixe teña asinado un instrumento tal de ventilaren as súas disputas mediante a arbitraxe do CNUDMI $^{18}$. Nesta modalidade, a autonomía das partes á hora de nomear aos árbitros abrangue a potestade de establecer unha autoridade nominadora, é dicir, una persoa encargada de nomear por si propia aos árbitros, tentando garantir coa selección a candidatos imparciais (art. 6 Regulamento CNUDMI), mais só en caso de que o procedemento se vexa bloqueado pola actividade das partes. Asemade, reláxanse os criterios en canto a lei aplicábel, de xeito que son as partes as que deben decidir neste extremo e, en ausencia de acordo, será o propio tribunal de arbitraxe quen decida a lei que aplicará (art. 35 Regulamento CNUDMI). Por último, cómpre subliñar que esta modalidade de arbitraxe non establece ningún mecanismo de control da legalidade do laudo, é dicir, ningún organismo, nin estatal nin internacional, poderá anular o laudo no caso de que este contraveña ou aplique erroneamente a normativa correspondente.

Cómpre atender tamén ao mecanismo regulado no TLCAN, asinado en 1994. O TLCAN contén diversas cláusulas referentes á harmonización das regulacións dos tres Estados implicados: México, Canadá e os EUA. E, polo tanto, é esperábel que sexa o modelo máis parecido ao que se baralle no bocexo do Tratado entre a UE e os EUA.

O instrumento do TLCAN recoñece ao demandante a posibilidade de elixir ben entre acudir a un tribunal ordinario do Estado demandado (Art. 1121 TLCAN) ou ben entre o Convenio do CIADI ou o do CNUDMI (art. 1120 TLCAN), mais neste último caso establece unha serie de peculiaridades, entre as cales a máis importante é que designa como lexislación aplicábel a do propio Tratado, co cal o Dereito nacional queda nun segundo plano, cando non se exclúe a posibilidade de aplicar a lexislación propia do Estado destinatario das inversións. No relativo ao control dos laudos, o Tratado remítese ao disposto nas nomeadas regulacións.

Pola súa banda, a arbitraxe ISDS sería, en resumidas contas, como segue ${ }^{19}$ : unha empresa estranxeira con cuxo Estado de orixe o Estado receptor tivera asinado un TPPI podería iniciar pola súa propia vontade un procedemento arbitral; o Estado demandado non podería evitar tal procedemento sen grave perxuízo para os seus intereses, pois o procedemento seguiría adiante ${ }^{20}$ e, nese caso, practicaríase proba e a empresa alegaría o Dereito que considerase oportuno, de xeito tal que, sen contradición por parte do Estado, o laudo arbitral sería con seguridade totalmente perxudicial para o Estado demandado.

\footnotetext{
${ }^{18}$ Existen TPPIs que optan por outros mecanismos no lugar da CNUDMI: a arbitraxe perante a Cámara de Comercio de Estocolmo, a arbitraxe perante a Cámara de Comercio Internacional e a arbitraxe perante a Corte Permanente de Arbitraxe, entre outras. Porén, por mor do espazo e do feito de que, segundo soen admitir estes propios regulamentos, están baseados no Regulamento da CNUDMI, o autor desbotou a posibilidade de abordar o seu estudo

${ }^{19}$ Para unha análise pormenorizada do procedemento arbitral, vid. BILLET, J.; International investment arbitration. A practical Handbook; Ed. Maklu, Amberes, 2016, páxs. 59-73; DUGAN, C.; WALLACE, D.; RUBINS, N. e S, ABAHI, B.; Investor-State Arbitration; Oxford University Press, Oxford, 2008, páxs. 117-182; FERNÁNDEZ MASIÁ, E.; Arbitraje en inversiones extranjeras: el procedimiento arbitral en el CIADI; Tirant Lo Blanch, Valencia, 2004, páxs. 175-346; e CROFT, C.; KEE, C. e WAINCYMER, J.; A guide to the UNCITRAL Arbitration Rules; Cambridge University Press, Cambridge, 2013

${ }^{20}$ Vid. Art. 45 do Convenio CIADI e art. 30 do Regulamento CNUDMI 2010
} 
Tralo comezo da arbitraxe, ámbalas dúas partes deberán, con carácter xeral, nomear un árbitro cada unha e, logo, eses árbitros deberán pórse de acordo en quen deberá ser o terceiro árbitro. Após disto comezaría o procedemento e cada parte debería procurar por si propia asesoramento xurídico especializado. O proceso pode durar anos, sendo o normal que se celebre a porta pechada, co cal o control público das deliberacións non existe $^{21}$. Finalmente, o laudo arbitral é de moi difícil control por unha segunda instancia e, ademais, os Estados raramente logran a revisión dos laudos ${ }^{22}$. No caso de que o contido do laudo sexa condenatorio para o Estado e o obrigue a pagar unha indemnización á empresa demandante, o Estado non ten escapatoria, pois múltiples son os mecanismos cos que contaría a empresa beneficiada ${ }^{23}$ : principalmente, aplicando a Convención sobre Recoñecemento e Execución de Sentenzas Arbitrais estranxeiras de $1958^{24}$ ou, segundo algún autor, procurando obter a execución do laudo por algunha autoridade competente, buscando protección diplomática, revendendo a obriga pecuniaria nun mercado secundario a un comprador con mellores opcións de cobrar a débeda, etc ${ }^{25}$.

Por último, debe facerse referencia ao feito de que en varias ocasións un mesmo Estado ten asinado unha cláusula arbitral de ISDS co gallo dun TPPI e, á vez, un acordo individual co inversor particular polo cal as partes acordan ventilar as súas demandas perante tribunais nacionais. Nestes casos, xurde un conflito sobre a norma aplicábel. Débese diferenciar aquí, por unha banda, entre disputas por mor de responsabilidade meramente contractual, como por exemplo que un determinado Estado non queira aboar o prezo completo dun contrato de obras públicas porque a obra foi rematada a destempo e, por outra banda, aquelas controversias sobre materias reguladas no TPPI, como por exemplo, unha modificación da lexislación sobre seguridade no traballo que obrigue ás empresas a investir diñeiro máis nesta materia.

O criterio que soe seguirse é que aqueles conflitos debidos a responsabilidade contractual serán resolvidos polos tribunais ordinarios e aqueloutros que xurdan por mor da suposta violación do acordado no TPPI, serán resoltas mediante a arbitraxe ISDS ${ }^{26}$. Mais, poden darse casos nos que un mesmo feito poda ser avaliado dende a perspectiva do cumprimento contractual e a do respecto do TPPI.

Isto último aconteceu no caso Compañía de Aguas del Aconquija S.A. e Vivendi c. Arxentina. Neste asunto, o tribunal de arbitraxe do CIADI declarou que non tiña competencia para entrar a coñecer do fondo, pois a suposta violación do TBI por parte de Arxentina producirase por causa dun incumprimento contractual, dun determinado

\footnotetext{
${ }^{21}$ EBERHARDT, P; OLIVET, C.; Profiting from injustice, Corporate Europe Observatory/ Transnational Institute, Bruxelas/Amsterdam, 2012, páx. 13

Dispoñíbel en https://www.tni.org/files/download/profitingfrominjustice.pdf

22 Íbid. páx. 14.

${ }^{23}$ Unha excepción a isto é o caso Yukos, onde a Federación Rusa conseguiu que o Tribunal do Distrito da Haia declarase recentemente que o laudo deste caso -cuxa contía era a máis alta da historia- fose declarado inválido. A causa non foi procesual, senón de Dereito internacional: ao non ter Rusia ratificado a Carta Europea de Enerxía, grazas á cal os accionistas de Yukos abriran o procedemento contra Rusia, a arbitraxe era inválida. Unha tradución non oficial ao inglés da sentenza pode ser atopada aquí: http://uitspraken.rechtspraak.nl/inziendocument?id=ECLI:NL:RBDHA:2016:4230

${ }^{24}$ Vid. Artigos III e IV da Convención, da que é parte o Reino de España, xunto con outros 155 Estados

${ }^{25} \mathrm{VVAA}$; Government perspectives on investor-state dispute settlement: a progress report, $\mathrm{OECD}$, Paris, 2012, páx. 12

Dispoñíbel en http://www.oecd.org/daf/inv/investment-policy/ISDSprogressreport.pdf

${ }^{26}$ FERNÁNDEZ MASIÁ, E.; Tribunales nacionales... páx. 42
} 
contrato que estipulaba que as partes deberían acudir á xurisdición ordinaria para resolver calquera controversia que nacera da aplicación do mesmo. Posteriormente, o laudo foi anulado parcialmente por un comité ad hoc e un segundo tribunal arbitral declarou que un acto de Estado podería ser ilícito dende a perspectiva do Dereito internacional e á vez perfectamente lícito dende a perspectiva do Dereito interno; deste xeito, o tribunal de arbitraxe estableceu que cando se tratase de facer valer as disposicións dun tratado, a existencia nun contrato privado dunha cláusula de submisión aos tribunais do Estado que contrata cunha empresa estranxeira non podería operar como impedimento á aplicación do tratado ${ }^{27}$.

FERNÁNDEZ MASIÁ advirte que isto pode entrañar un perigoso privilexio para as empresas demandantes, dado que, na práctica, nunha «grande maioría das ocasións onde xorden diferenzas entre as partes, tales diferenzas son a consecuencia dunha violación das concretas obrigas contractuais ${ }^{28}$. Deste modo, unha empresa demandante pode alegar a violación dun TPPI a través dun incumprimento contractual por parte do Estado, de sorte tal que o tribunal arbitral podería entrar a coñecer do suposto incumprimento contractual con carácter previo a decidir sobre a violación do TPPI.

Para ilustrar isto último poderíamos imaxinar un caso no que unha multinacional estranxeira tivese concedida unha autorización para o aproveitamento dos recursos mineiros dunha determinada zona. A multinacional podería ter asinado un contrato hai moitos anos onde o Estado se obrigara a garantir a cesión do dereito de explotación mineira por un tempo de 60 anos, a cambio dun forte investimento económico por parte da empresa e da contratación dunha porcentaxe mínima de traballadores con nacionalidade do Estado receptor. Imaxinemos que, estando as cousas así, o Estado receptor asina un TPPI co Estado de orixe da multinacional, onde se prohiba calquera diferenciación entre empresas nacionais e internacionais. Imaxinemos que nese Estado ás empresas autóctonas non se lles impón a obriga de contratar un número mínimo de traballadores con cidadanía do propio Estado. Daquela, a empresa atoparía un subterfuxio legal para poder rachar coa obriga de contratar unha porcentaxe mínima de traballadores nacionais, pois ben, se o Estado decidise a causa diso rescindir o contrato que ten coa multinacional, a esta abondaríalle con interpor un litixio arbitral ISDS, onde previsibelmente o tribunal condenaría ao Estado receptor por violación do tratado, ao obrigar á multinacional a ter que asumir unha obriga que o Estado non impón ás empresas nacionais: o de contratar un número mínimo de traballadores autóctonos. Se, pola contra, este mecanismo non estivera dispoñíbel, a empresa non podería cubrirse as costas fronte un eventual incumprimento do contrato pola súa parte, pois previsibelmente, a xurisdición ordinaria ditaminaría que a rescisión do contrato por parte do Estado é válida, posto que a empresa incumprira unha das condicións do contrato.

\section{AS CRÍTICAS AO ISDS}

\footnotetext{
${ }^{27}$ Caso CIADI No. ARB/97/3, Decisión sobre a anulación, de 3 xullo de 2002, parágrafos 101 a 115

${ }^{28}$ FERNÁNDEZ MASIÁ, E.; Tribunales nacionales... páx. 50
} 
As críticas ao sistema ISDS son múltiples. Para a súa exposición, poderemos botar man de tres categorías:

\section{Deficiencias constitucionais do ISDS}

Estas deficiencias farían referencia ás eivas na configuración institucional da arbitraxe ISDS, que porían en tea de xuízo carácteres como a imparcialidade ou a independencia dos tribunais arbitrais. Neste sentido, tense denunciado en diversas ocasións a falta de neutralidade dos árbitros, o que se debe, segundo o informe resultante da mesa redonda da Organización para a Cooperación e o Desenvolvemento Económico a aspectos como que as repetidas interaccións entre os árbitros, que soen formar un grupo pechado, en variados roles como a asesoría legal ou mesmo a arbitraxe, dá pé a un nepotismo que podería ter como consecuencia que moitos casos sexan resolvidos non tanto en atención aos méritos alegados polas partes, senón en función doutros factores ${ }^{29}$.

Ademais, apúntase unha tendencia nos árbitros do mecanismo ISDS a traballar como asesores xurídicos noutros preitos arbitrais ao servizo das grandes corporacións; o que se debe pór en relación coa escasa presenza de funcionarios estatais especialistas en Dereito de inversións na selecta listaxe de árbitros ISDS. Por último, refírense ademais que existen certos problemas relacionados coa formación profesional dos árbitros, por canto estes soen ter formación legal eminentemente no ámbito mercantil ou societario, o que soe dar pé a unha falta de sensibilidade fronte aos problemas de Dereito público ${ }^{30}$ que conforman o outro feixe de intereses en conflito dentro dos preitos arbitrais ISDS.

Alén do anterior, na declaración pública do 31 de agosto de 2010 feita por case oitenta académicos do mundo anglosaxón, sinalouse que, na súa constitución actual, «a arbitraxe establecida nos TPPIs non é un método xusto, nin independente, nin balanceado para a resolución de disputas sobre investimentos» ${ }^{31}$. Ao abeiro disto, aproveitouse para apuntar que os cidadáns particulares, as comunidades locais e as organizacións da sociedade civil deberían ter lexitimación para participar nos procesos de toma de decisións que afectan aos seus dereitos e intereses no contextos destes conflitos $^{32}$. Asemade, tense criticado a falta de transparencia do tribunal ${ }^{33}$ e resulta que mesmo persoas que son favorábeis á arbitraxe ISDS teñen chegado a recoñecer que se debería mellorar a transparencia dos procedementos, por canto neles sóense tratar intereses de carácter político ${ }^{34}$.

Tamén se produce, segundo o informe da OCDE, unha gran diferenza na información dispoñíbel polos diversos actores ao momento de elixir aos árbitros, de xeito que as grandes firmas de avogados soen coñecer mellor as preferencias ideolóxicas e os perfís das persoas autorizadas para realizar este tipo de arbitraxe, o que as coloca nunha posición de superioridade con respecto ao resto de actores ${ }^{35}$, elevando así a cotización das firmas, que poden supoñer un gran desembolso económico para as partes.

\footnotetext{
${ }^{29}$ VVAA; Government perspectives... Páx. 15

30 Íbid. Páx. 17

${ }^{31}$ VVAA.; Public statement on the international investment regime, Londres, 2010, Páx. 2 parágrafo 8

32 Íbid. Páx. 2 parágrafo 9

${ }^{33}$ BILLET, J.; International investment... páx. 85

${ }^{34}$ Así opina Elena GUTIÉRREZ, secretaria xeral da Corte de Arbitraxe de Madrid, segundo se recolle en http://economia.elpais.com/economia/2015/07/08/actualidad/1436364793 777628.html consultado o 14/10/15

${ }^{35}$ VVAA; Government perspectives... Páx. 16
} 
Afondando nesta categoría de deficiencias constitucionais da arbitraxe ISDS, cómpre facer referencia ao aspecto lucrativo do sistema, moitas veces denunciado. O Corporate Europe Observatory, en colaboración co Transnational Institute publicaron a finais do 2012 un informe titulado Profiting from injustice, onde fan unha incisiva crítica a este aspecto, apuntando que «segundo viu aumentando o número de conflitos, a arbitraxe converteuse nunha máquina de facer cartos por dereito propio» ${ }^{36}$, que é considerada polo Instituto das Nacións Unidas para a Formación e a Investigación como a «área de maior desenvolvemento dentro do Dereito internacional», o que non é de estrañar, posto que se calcula que, por termo medio, o custo total dun procedemento perante un tribunal de arbitraxe ISDS acada unha media de 8 millóns de dólares, é dicir, ao redor de 7 millóns de euros, podendo chegar a varias ducias de millóns ${ }^{37}$. Este alto custe tamén ten sido denunciado con asiduidade ${ }^{38}$.

\section{O ISDS como instrumento de disuasión da autonomía democrática dos Estados}

Dentro desta categoría, cómpre comezar por recoller o obxectivo xeral que guiou a popularización do ISDS nas décadas anteriores: trátase de garantir unha resolución xusta, especialmente naqueles países onde a independencia xudicial se acha diminuída ${ }^{39}$. Seguindo este criterio, a inclusión do mecanismo ISDS é difícil de explicar no Tratado entre os EUA e a UE, especialmente cando os últimos datos dispoñíbeis indican que todos os sistemas xudiciais dos Estados implicados aproban neste parámetro $^{40}$.

Daquela, hai algo que non encaixa. En realidade, parece que o ISDS serve para actualizar a estratexia da diplomacia de canoneiro ${ }^{41}$. É dicir, é un xeito de que as multinacionais podan frear aquelas decisións políticas que lles resultan gravosas. Para isto, póñense en xogo diversos dispositivos.

O primeiro dispositivo consiste en permitir que os organismos arbitrais gocen dunha ampla capacidade de interpretación dos feitos, deixando a porta aberta a encaixar as máis variadas accións estatais dentro dos supostos de feitos das contravencións do tratado $^{42}$; noutras palabras, o tribunal ten a posibilidade de facer unha interpretación extensa dos feitos políticos que permita subsumilos nun suposto de feito que implique a violación do Tratado. E, en efecto, tense feito así en varias ocasións, como cando os tribunais de arbitraxe interpretan que algunhas medidas destinadas a garantir a lexislación interna constitúen unha violación dos TPPI. O caso máis famoso pode que

\footnotetext{
${ }^{36}$ EBERHARDT, P; OLIVET, C.; Profiting from... Páx. 15

${ }^{37}$ Íbid. Páx. 15

${ }^{38}$ BILLIET, J.; International Investment Arbitration... páx. 86

${ }^{39}$ Vid. DUGAN, C.; WALLACE, D.; RUBINS, N. e S, ABAHI, B.; Investor-State Arbitration; Oxford University Press, Oxford, 2008, páxs. 13 e 15; e FERNÁNDEZ MASIÁ, E.; Arbitraje en inversiones extranjeras: el procedimiento arbitral en el CIADI; Ed. Tirant Lo Blanch; Valencia, 2004, páx. 16

${ }^{40}$ SCHWAB, K. (Ed.); The Global Competitivenes Report 2013-2014, World Economic Forum, Xenebra, 2015, páx. 415

Dispoñíbel en http://www3.weforum.org/docs/WEF_GlobalCompetitivenessReport 2013-14.pdf

${ }^{41}$ Durante o século XIX e mediante a diplomacia de canoneiro, os Estados do centro do Sistema-mundo despregaban as súas forzas militares, ameazando aos países da periferia, co obxectivo de obrigarlles a desistir de certas políticas económicas perxudiciais para os intereses do capital

${ }^{42}$ VAN HARTEN, G.; Investment Treaty Arbitration and Public Law; Oxford University Press, Oxford, 2007, páx. 122 e ss.
} 
sexa o de Occidental Petroleum Corp. v. Ecuador, onde o Estado suramericano foi obrigado a satisfacer unha indemnización de 2.300 millóns de dólares en concepto de «trato inxusto» logo de que o goberno decidira rescindir o contrato que tiña coa multinacional, a pesar de que esta previamente violara o pactado no propio contrato ao asinar unha subcontratación da súa concesión que permitía a outra empresa estranxeira extraer petróleo do terreo adxudicado a Occidental Petroleum sen ter o visto bo das autoridades públicas, é dicir, sen seguir o procedemento administrativo requirido para obter a concesión legal da explotación ${ }^{43}$.

Este dispositivo, que permite unha gran discrecionalidade ao tribunal arbitral, ten sido denunciado na declaración pública do 31 de agosto de 2010 ao que se fixo referencia anteriormente. $\mathrm{O}$ documento explica que nas adxudicacións feitas por árbitros internacionais contra os Estados téñense realizado interpretacións expansivas da linguaxe dos tratados que priorizaban a protección da propiedade e dos intereses económicos das corporacións por sobre o Dereito regulador ${ }^{44}$. Para que elo sexa posíbel, é necesario que existan nos TPPIs unha constelación de termos vagamente determinados, onde caiban as máis diversas interpretacións. A propia Comisión Europea recoñece que eses termos soen ser os de «expropiación indirecta»e «tratamento xusto e equitativo» ${ }^{45}$.

Ademais, hai que recoñecer que as cuantiosas condenas serven como potente coacción para disuadir aos Estados de participar neste tipo de procedementos, preferindo así estes ben chegar a acordos extra arbitrais, ben non levar ao cabo as decisións que poidan perturbar a seguridade dos investimentos das empresas multinacionais. Tamén é de destacar que, a pesar de todo o exposto, hai certa unanimidade en aceptar que o ISDS non ten un impacto significante no aumento dos fluxos de inversión ${ }^{46}$, o cal é o obxectivo confesado polos negociadores do ATCI.

Por último, algúns expertos aventúranse a denunciar o que cualifican como forum shopping. Para comprender isto, cómpre lembrar, como xa se dixo, que moitas lexislacións prevén sistemas ordinarios de resolución de conflitos que visan a garantir o dereito das empresas en caso de excesos por parte das Administracións Públicas. Porén teren a mesma finalidade e incluso maior eficacia á hora de tutelar os intereses das grandes empresas, algunhas destas prefiren especular coa vía na cal a indemnización soia ser maior ${ }^{47}$. A esta tendencia a elixir o mecanismo de resolución de conflitos máis rendíbel denomínaselle de forum shopping, que podería traducirse como «consumo de foros ${ }^{48}$. Tanto este último fenómeno en particular, como o ISDS en xeral, están reservados ás empresas estranxeiras, dado que as empresas autóctonas non poden

\footnotetext{
${ }^{43}$ Algo similar aconteceu en CMS c. Arxentina (par. 281), no que o tribunal interpretou que, as medidas ordeadas polo goberno arxentino a través do plan de recuperación económica de 1989, no sentido de baixar as tarifas do gas para toda a poboación, debido á grave crise económica daquel momento, eran contrarias ao concepto de trato xusto e equitativo

${ }^{44}$ VVAA.; Public statement... Páx. 1

45 COMISIÓN EUROPEA, «Fact sheet on Investment Protection and Investor-to-State Dispute Settlement un EU Agreements», Bruxelas, 2014, páxs. 7 e 8

${ }^{46}$ VVAA; Government perspectives... Páx. 13; Nun sentido parecido, WALLACH de Public Citizen afirma: «os países non necesitan aceptar infraccións claras á súa soberanía nacional, como a cláusula ISDS, para atraer investimentos. Brasil non ten asinado ningún acordo bilateral de inversións e é o principal obxectivo dos investimentos estranxeiros en América Latina». Cit. en GEORGE, S. (2015); Los usupardores, páx. 129

${ }^{47}$ VAN HARTEN, G.; Investment Treaty... páxs. 109 e 110

${ }^{48}$ VVAA; Government perspectives... Páx. 9
} 
recorrer a elas; este aspecto tamén ten sido denunciado numerosas veces e pode lerse como un detrimento da tutela dos dereitos das empresas autóctonas.

\section{3. Ámbitos concretos nos que o ISDS podería servir como bloqueo das políticas públicas dentro do Acordo para a Asociación Transatlántica do Comercio e o Investimento}

Para rematar este apartado, cómpre realizar unha breve referencia á derradeira categoría, isto é, aos ámbitos concretos nos que o ISDS podería servir como bloqueo das políticas públicas dentro do TPPI entre os EUA e a UE, xa que as empresas americanas poderían alegar a existencia de menos barreiras para as súas homólogas europeas en territorio americano do que para elas propias en territorio europeo. Dado que alude a asuntos que escapan á intención deste artigo, a exposición limitarase a referir a escolma elaborada por GEORGE ${ }^{49}$ : i) Prevención, seguridade, saúde e medioambiente: os estándares nestas materias son máis altos en Europa do que nos EUA, co cal unha harmonización neste sentido significaría unha redución dos estándares de seguridade en Europa; ii) Alimentación e agricultura: ábrese a porta á posíbel supresión dos indicadores xeográficos; iii) Substancias químicas: o Regulamento europeo de avaliación do risco é moi lento e garantista en comparación co mecanismos propio dos EUA; iv) Fracturación hidráulica e gas cortiza: nos EUA, a lexislación sobre seguridade da auga potable excepciónase nos lugares en que se practica o fracking, ademais, as corporacións poderían escudarse en dereitos de patente para evitar revelar que produtos utilizan para levar ao cabo esta técnica, o que fai moi complicado saber se a contaminación dun pozo se debe a esa práctica ou non; v) Propiedade intelectual e xigantes farmacéuticos: os oligopolios queren evitar que medicamentos xenéricos idénticos pero moito máis baratos podan entrar ao mercado, o que conseguirían harmonizando ambos mercados

\section{PRIMEIRO PROXECTO DE RESOLUCIÓN DE CONTROVERSIAS NO ATCI: O ISDS}

A Comisión Europea, máximo órgano executivo e lexislativo da UE, é a encargada de dirixir as negociacións do TPPI entre os EUA e a UE, pola parte europea. A pesar da opacidade do proceso de redacción e debate dos pormenores do Tratado, sábese que tanto a Comisión Europea como o Goberno dos EUA teñen defendido e argumentado a favor da inclusión do ISDS ao longo dos dous anos anteriores.

Nun primeiro momento, cando as negociacións aínda eran secretas, a Comisión tan só publicara unha ficha técnica ${ }^{50}$ na cal se recollía argumentación sobre a necesidade de incluír a cláusula ISDS nos TPPI, así como unha serie de directrices a seguir sobre a negociación das futuras cláusulas ISDS nos TPPI nos que a UE fora parte. Naquel momento, a argumentación da Comisión era tallante: os investimentos son un factor crítico para o crecemento económico e o emprego ${ }^{51}$ e, a miúdo, as corporacións que invisten no estranxeiro vense inmersas en asuntos que non poden ser resoltos a través

\footnotetext{
${ }^{49}$ GEORGE, S.; Los usupardores, Ed. Icaria, Barcelona, 2015, páxs. 114-128

${ }^{50}$ Documento dispoñíbel en http://trade.ec.europa.eu/doclib/docs/2013/november/tradoc 151916.pdf

${ }^{51}$ COMISIÓN EUROPEA, Fact sheet on...Páx. 3
} 
dos tribunais ordinarios, de xeito tal que a provisión de mecanismos de protección dos investimentos outorga ás corporacións certeza xurídica e predicibilidade.

Porén, a Comisión non é allea ao principal conflito que subxace ao ISDS: o equilibrio entre a necesidade de protexer aos inversores e o dereito dos Estados a regular. E mesmo recoñece que algúns casos de arbitraxe ISDS fixeron nacer serias críticas na opinión pública, polo cal a Comisión entende que debe tratar de asegurar dous aspectos: por unha banda, eliminar a ambigüidade dos TPPI, para impedir que as decisións arbitrais supoñan unha ameaza para o dereito a regular dos Estados e, por outra banda, asegurar a transparencia e o xusto proceso nas decisións arbitrais ${ }^{52}$.

Daquela a sucinta ficha técnica apunta a dúas cuestións chave. Primeira, que os mecanismos de protección das inversións deben defender fronte a discriminación das empresas inversoras estranxeiras -tanto fronte empresas autóctonas como fronte a outras empresas estranxeiras que non fosen nacionais dos EUA-, fronte a expropiacións arbitrarias ou non xustamente compensadas, fronte ao tratamento inxusto e fronte a imposibilidade de transferir capital. Segunda, que cómpre traballar para acadar a claridade e mellora das normas de protección dos investimentos, detallando os casos en que se pode apreciar expropiación indirecta e trato xusto e equitativo, así como impedir que unha mesma empresa interpoña varias demandas de arbitraxe ou utilice o ISDS de xeito temerario e, finalmente, traballar cara unha maior transparencia do sistema.

Logo da filtración do borrador do TPPI entre os EUA e a UE, en marzo de 2014, a Comisión publicou un breve documento ${ }^{53}$ onde se remarcaba a importancia de incluír a arbitraxe ISDS dentro do tratado cos EUA, á vez que se engadían dous novos obxectivos: o establecemento dun sistema de apelacións e impedir que os tribunais de arbitraxe puideran anular unha medida gobernamental. Esta segunda medida chama a atención, por canto os tribunais de arbitraxe non teñen nin tiveron nunca potestade para anular actos gobernamentais: a coacción do ISDS, como se explicou, canalízase por outras vías.

Máis adiante, en xaneiro de 2015, a Comisión publica unha folla de datos ${ }^{54}$ onde volve defender as razóns para garantir a arbitraxe ISDS no Tratado, á vez que adianta que, durante o primeiro trimestre dese ano establecerá unha rolda de contactos con gobernos, Parlamento Europeo e stakeholders ${ }^{55}$ con miras a redactar un primeiro esquema de reforma do sistema de protección das inversións que tivese por obxectivo garantir o dereito dos gobernos a regular e asegurar á vez unha maior transparencia do sistema.

En marzo de 2015, nun momento en que a campaña contra o ISDS tiña un respaldo crecente na opinión pública, a Comisión publica un pequeno informe ${ }^{56}$ no que dá conta de varios datos acerca do ISDS. A mudanza no discurso é palmaria. Agora, do que se

\footnotetext{
${ }^{52}$ Íbid. Páx. 6

${ }_{53}^{53}$ Documento dispoñíbel en http://trade.ec.europa.eu/doclib/docs/2014/march/tradoc 152290.pdf

${ }^{54}$ Documento dispoñíbel en http://trade.ec.europa.eu/doclib/docs/2015/january/tradoc_153018.5\%20Inv\%20Prot\%20and\%20ISDS.pd $\mathrm{f}$

${ }^{55}$ Sobre o concepto de «stakeholder»-que se pode interpretar como parte interesada-, GEORGE ten criticado que o termo fai referencia a unha persoa con intereses financeiros ou comerciais que se superpoñen por riba dos intereses que nacen da súa pertenza a unha comunidade política de base territorial. A Comisión Europea, segundo GEORGE, prefire falar de stakeholders ca de cidadáns, quen, ademais de intereses materiais, teñen intereses políticos.

${ }^{56}$ Documento dispoñíbel en http://trade.ec.europa.eu/doclib/docs/2015/january/tradoc 153046.pdf
} 
trata non é de protexer os intereses dos inversores estranxeiros, senón de «prover dun foro neutral para resolver as disputas» ${ }^{57}$. E o ISDS é presentado como un dispositivo avalado pola tradición, con boas credenciais e que, na práctica, as empresas que máis botan man del teñen a súa sede nos países da $\mathrm{UE}^{58}$, non sendo só grandes corporacións as beneficiadas ${ }^{59}$.

Xa en maio de 2015, nun dos momentos de maior tensión pública en relación ao Tratado, e con miras á votación á que se ía someter a cláusula ISDS no Parlamento Europeo, sae do prelo o documento programático da Comisión ${ }^{60}$. Cómpre pór de relevo que, no deseño institucional da UE, o Parlamento Europeo ten principalmente unhas funcións consultivas, e a súa potestade lexislativa, residual, está compartida co resto de institucións da UE no que ten a ver coa aprobación dos Tratados Internacionais sobre comercio internacional. Así que a votación do día 28 de maio só tiña carácter consultivo. A pesar diso, a Comisión decidiu defender a súa postura enxalzando os seus logros noutros TPPIs -como o xa en vigor, con Singapur, ou o que se estima pechar con Canadá, cuxas negociacións están moito máis avanzadas- máis concretamente á hora de mellorar a obxectividade, a igualdade de armas procedimentais das partes e as garantías da arbitraxe ISDS, así como unha sincera análise das deficiencias e dos retos que quedaban por diante.

En síntese, a Comisión expón que:

- Tense reafirmado, no Acordo Económico e Comercial Global, coñecido polas súas siglas en inglés, $A G C E$, (TPPI entre Canadá e a UE), o dereito dos gobernos a regular, especialmente en áreas sensíbeis, como a sanidade ou o medio ambiente. Se ben o certo é que esta declaración é recollida tan só no Preámbulo do Tratado $\mathrm{AGCE}^{61}$, co cal, tecnicamente, non debería ser máis do que unha directriz que guiase a interpretación do Tratado. É dicir, non ten a forza necesaria para ser directamente aplicábel en caso de conflito.

- Definiuse o concepto chave de «trato xusto e equivalente» e achegáronse parámetros para discernir se, nun caso concreto, se produciu unha «expropiación indirecta». Efectivamente, no Tratado AGCE, baixo esta categoría (Sección 4, art. X.9.2 do AGCE) inclúense a denegación da tutela xudicial, decisións manifestamente arbitrarias, hostilidade fronte aos inversores e, sorprendentemente unha subcategoría tremendamente ampla: discriminación. Pero, neste caso concreto, os parámetros que serven para dilucidar se se produciu unha expropiación indirecta deben considerarse como extremadamente $\operatorname{vagos}^{62}$, co cal a Comisión deixa aberta a porta a interpretacións amplas que supoñan unha condena ao Estado receptor.

\footnotetext{
${ }^{57}$ COMISIÓN EUROPEA, «ISDS. Some facts and figures», Bruxelas, 2015, páx. 3

58 Íbid. Páx. 6

59 Íbid. Páx. 4

${ }^{60}$ Documento dispoñíbel en http://trade.ec.europa.eu/doclib/docs/2015/may/tradoc 153408.PDF

${ }^{61}$ Unha versión do AGCE, tamén coñecido polas súas siglas en inglés, CETA, pode ser consultada aquí: http://trade.ec.europa.eu/doclib/docs/2016/february/tradoc 154329.pdf

62 Recóllense no Anexo X.11.2 do Tratado e fan referencia a 1) impacto económico da medida, 2) duración da medida, 3) interferencia coas expectativas de retorno dos investimentos e 4) o carácter das medidas, especialmente a súa intención e contexto
} 
- Téñense prevido as prácticas de forum shopping, por exemplo, prohibindo a posibilidade de que unha reestruturación dunha sociedade mercantil poda dar pé ao nacemento da lexitimación para interpor a arbitraxe ISDS. Ou sexa, tense tratado de impedir que as multinacionais boten man da súa natureza líquida para poder aparecer como estranxeiras cando en realidade non o son ${ }^{63}$. Asemade, vense de prohibir que as empresas mail-box, é dicir, aquelas cun domicilio legal ficticio nun determinado país -caso daquelas que se queren beneficiar do dumping fiscal- podan valerse desa condición para acudir á vía ISDS.

- Tense pulado cara unha maior transparencia do proceso. O cal se fixo adoptando as normas de transparencia do CNUDMI, que permiten o acceso público a case todos os documentos presentados polas partes e aos actos do tribunal arbitral. Alén de máis, estableceuse no AGCE a publicidade das audiencias e a posibilidade de que terceiras partes interesadas presenten alegacións.

- Outorgóuselles aos gobernos a posibilidade de pactaren interpretacións de certas cláusulas, de xeito que esas interpretacións sexan vinculantes para o tribunal.

- Tense redactado un código de conduta para os árbitros, coa intención de asegurar o respecto destes de certos estándares éticos e profesionais.

- Creáronse, así mesmo, regras para asegurar a inadmisión de demandas sen fundamento.

- Establecéronse os criterios de imposición de custas procesuais, que correrán a cargo de quen vexa desestimadas as súas pretensións. É dicir, quen debe pagar o xuízo será quen o perda. Esta medida era unha das máis buscadas polas voces críticas, pois moitas veces, os altos custes da arbitraxe ISDS servían, segundo se ten argumentado, para disuadir aos Estados de seguiren adiante co procedemento, dando pé a acordos extra-arbitrais que, segundo datos da Comisión Europea, acadaban o $28 \%$ de todos os $\operatorname{casos}^{64}$.

- Establecéronse mecanismos para evitar que unha mesma empresa bote man da vía xudicial ordinaria e da vía arbitral para resolver un mesmo asunto, con fundamentos de Dereito distintos, é dicir, prohíbese que as empresas podan obter dobre compensación por un mesmo feito.

En definitiva, a Comisión Europea recoñece que ten traballado recentemente nas negociacións do TPPI entre Canadá e a UE para garantir uns estándares mínimos que impidan o abuso de dereito por parte das empresas multinacionais, que provoquen o bloqueo de toda posibilidade de lexislar e regular dos Estados por parte dos árbitros. Preténdese avalar así, en definitiva, a obxectividade do tribunal arbitral.

\footnotetext{
${ }^{63}$ Neste sentido, afamado foi o caso Phillip Morris v. Australia, onde a filial asiática da tabacaleira, con sé en Hong Kong adquiriu a filial australiana para así poder demandar ao Estado australiano ao abeiro dun TPPI asinado entre Hong Kong e Australia. Meses antes, ante a mudanza na lexislación sanitaria australiana que incluía cambios na información sobre o carácter nocivo dos cigarrillos, a propia filial australiana da multinacional demandara ao Estado perante a vía ordinaria sen éxito. Algo semellante aconteceu no Caso Lone Pine v. Canada, xa comentado máis arriba

${ }^{64}$ COMISIÓN EUROPEA, «Concept Paper», Bruxelas, 2015, páx. 7
} 
Abonda dicir que nas Administracións estatais de Xustiza xa se articulan mecanismos que garantan eses tres obxectivos -obxectividade do tribunal, limitacións á potestade xurisdicional e proceso igualdade de armas procesuais-, e articúlanse con moita máis infalibilidade do que na arbitraxe ISDS. Ademais, os ordenamentos xurídicos internos soen incluso ir alén, establecendo a posibilidade de apelación en materia civil, cristalizando como Dereito fundamental o dereito á tutela xudicial efectiva e regulando as prohibicións e incompatibilidades do persoal con potestade xurisdicional e doutras persoas que participan no proceso, e teno feito de xeito moito máis pormenorizado do que no ISDS. Daquela, o esforzo, aínda que necesario, seguía antollándose insuficiente.

\section{SEGUNDO PROXECTO DE RESOLUCIÓN DE CONTROVERSIAS NO ATCI: O TRIBUNAL DE INVERSIÓNS}

Cómpre agora facer unha viaxe no tempo ata a segunda semana de xuño de 2015. Nesa semana, o mércores 10, o Parlamento Europeo debería ter votado un informe que sintetizara as opinións de todos os comités internos da cámara. Se ben o PE non ten potestade para negociar o Tratado da ATCI -o cal é competencia da Comisión-, nos procedementos de negociación e aprobación dos tratados internacionais en materia de comercio é imprescindíbel a votación favorábel do PE na derradeira fase (art. 218.6 TFUE). Así, mediante ese informe, o PE podería ter limitado de xeito mediato o albedrío da Comisión, establecendo liñas vermellas cuxo exceso implicaría o parecer desfavorábel do PE e a conseguinte desaprobación do Tratado na derradeira fase.

A prensa informou que o relatorio, coñecido como Lange Report ${ }^{65}$, polo apelido do seu redactor, non desbotaba a arbitraxe ISDS, a pesar de que o devandito relator, o socialdemócrata alemán Bernd Lange, se tivera posicionado en repetidas ocasións contra tal mecanismo. Isto, en termos xerais, é certo; pero, en realidade, a proposta ía alén e pretendía deseñar un novo mecanismo.

Xa no documento de traballo para a redacción do informe podíase ler:

«Dado o desenvolvemento dos sistemas legais na UE e nos EUA, un mecanismo de resolución de conflitos entre Estados e o recurso aos tribunais estatais son as ferramentas máis axeitadas para resolver preitos sobre investimentos.

No caso de que se inclúan cláusulas ISDS, semella claro que será importante realizar ulteriores reformas ao modelo actual, para evitar os problemas que xorden da aplicación dos tratados bilaterais de comercio» ${ }^{66}$

E, finalmente, a opción asumida polo relator do informe foi a de evitar abordar o problema, se ben facendo fincapé en que o mecanismo negociado pola Comisaria debería pular pola inclusión de «xuíces públicos», visando na transparencia do seu

${ }^{65}$ Dispoñíbel en http://www.europarl.europa.eu/sides/getDoc.do?pubRef=-//EP//TEXT+REPORT+A82015-0175+0+DOC+XML+V0//EN

${ }^{66}$ PARLAMENTO EUROPEO, (Comité de Comercio internacional); «Working Document in view of preparing the draft report omn Parliament's report on the negotiations for the TTIP», Bruxelas, 2015; páx. 6 
nomeamento e que o sistema definitivo incluíse un sistema de apelación ${ }^{67}$. Indo alén, o relatorio explicitaba: «a medio prazo, un Tribunal Público de Investimentos podería ser o método máis apropiado para solucionar os conflitos» ${ }^{68}$.

A decisión de non posicionarse activamente contra o ISDS provocou a detracción da esquerda parlamentar e, nun momento crítico, o Presidente do PE, tamén socialdemócrata, decidiu aprazar a votación. Finalmente, nun momento de profundas críticas, o PE aprobou o informe un mes despois, con 436 votos a favor -liberais, populares e socialdemócratas- e 241 en contra -esquerda unitaria, verdes e lepenistas-, con case tres ducias de abstencións.

Facéndose eco da proposta do informe Lange, a Comisaria viuse forzada a presentar, a mediados de setembro, unha outra proposta que asegurase o apoio do PE unha vez concluídas as negociacións: O Tribunal de Investimentos. A comisaria Malmström presentou a nova proposta como unha superación do ISDS ${ }^{69}$. Recoñecendo que o ISDS erguía suspicacias dentro da opinión pública, a comisaria explicaba no seu blogue que a nova proposta debería presentar as mesmas garantías do que os tribunais domésticos, ademais de funcionar de xeito transparente e suxeito a principios democráticos. Así, afirma: «serán xuíces e non árbitros quen resolvan os preitos» ${ }^{70}$. Trataríase de xuíces nomeados con antelación polas partes do Tratado e regularíanse unha serie de ferramentas para solucionar os conflitos de intereses, alén de instituír un mecanismo de apelación, en definitiva: a Comisión comprometíase a establecer un «sistema público de xustiza».

O Memorándum ${ }^{71}$ da Comisión expón a reforma centrándose en dous eixos: por unha banda, a protección brindada ao investidor e, pola outra, a resolución de conflitos sobre investimentos e o sistema do Tribunal de Investimentos. No referente ao primeiro, o Memorándum fai fincapé na protección ao dereito a regular, é dicir, o impedimento de que o ISDS poda servir para poñer eivas ás políticas dos gobernos. Este discurso alimenta concepcións erróneas, pois, como se advertiu máis enriba, a arbitraxe ISDS nunca impediu que os Estados puideran regular, posto que en realidade non ten potestade para botar atrás as decisións dos gobernos. O ISDS actúa dun xeito máis sutil: ao establecer indemnizacións para as empresas perxudicadas por unha decisión gobernativa, o ISDS disuade e castiga. Disuade aos gobernos de aplicar medidas que danen ás compañías multinacionais e castigan aos gobernos que decidiran seguir adiante a pesar do risco latente. Emporiso, o Memorándum si introduce un avance importante, pois explícase que, no caso da UE, o Tratado non poderá servir para limitar a prohibición de axudas estatais feita polas institucións da UE.

Finalmente, a modo de contrapeso, debúllase unha liña vermella conformada por cinco garantías básicas que terán que ser observadas por todas as institucións estatais e europeas: imposibilidade de expropiar sen compensación, imposibilidade de impedir a transferencia de capital resultante dun investimento, o compromiso de garantir un trato xusto e equitativo e a seguridade física, o compromiso de que os gobernos respectarán

\footnotetext{
${ }^{67}$ Íbid. Páx. 18

${ }^{68}$ Íbid

${ }^{69}$ Así, escribiu no seu blogue: «propoño establecer un sistema moderno e transparente de resolución de preitos entre investidores e Estados: o sistema do Tribunal de Investimentos. Este novo sistema reemprazará ao vello modelo ISDS»

${ }^{70}$ Íbid.

${ }^{71}$ Dispoñíbel en http://trade.ec.europa.eu/doclib/press/index.cfm?id=1365
} 
as obrigas contractuais que contraeran cos investidores e o compromiso de compensar por perdas nos investimentos en casos de conflitos armados. Só por estas causas, explica o Memorándum, poderá un investidor demandar a un goberno.

Por outra banda, no atinente á resolución de disputas, o Memorándum comeza enunciando: «o borrador da UE transforma fundamentalmente o sistema de resolución de conflitos de investimentos ao propoñer un sistema xudicial comparábel aos sistemas nacionais e internacionais». O devandito sistema lembra moito na súa composición ao Tribunal de resolución de reclamacións entre Irán e os EUA, establecido consonte ao disposto nos acordos de Alxeria ${ }^{72}$. estaría composto por dúas instancias, o Tribunal de Investimentos e o Tribunal de Apelacións. O primeiro, formado por 15 xuíces -cinco nacionais dos EUA, cinco nacionais de Estados membros da UE e cinco nacionais de terceiros Estados-; o segundo, por seis -na mesma proporción que o anterior. Ambos tribunais, asegúrase no Memorándum, suxeitarían aos seus membros a uns requisitos éticos estritos, prohibindo a posibilidade de que estes podan actuar como asesores legais noutros procedementos de investimentos.

Asemade, dentro do mesmo epígrafe, o Memorándum anuncia que se seguirán traballando nas propostas da UE incluídas nos Tratados con Canadá e Singapur: completa transparencia, prohibición do forum shopping, control da interpretación por parte dos gobernos, posibilidade de inadmisión das demandas infundadas e imposición de custas á parte que vexa desestimadas todas as súas pretensións.

A pesar do anterior, as cousas mudan sensibelmente cando se le o borrador do texto da Comisión sobre o Tratado $^{73}$. O primeiro que salta á vista é a falta á verdade sobre a natureza dos Tribunais propostos. Non son, en absoluto, uns tribunais que funcionen de xeito análogo aos pertencentes aos sistemas xudiciais nacionais e internacionais, senón que seguen sendo tribunais de arbitraxe. Así despréndese do artigo 6 do borrador, onde se recollen as normas procesuais aplicábeis: a da Convención do CIADI e as regras do CNUDMI, se ben aquelas cuestións procesuais reguladas polo Tratado, é dicir, as que temos referido -composición e nomeamento do tribunal, método, particularidades, etc.substituirían ás ditas normativas internacionais.

E facer subsistir as regras de arbitraxe, moito máis vagas que calqueira lei de axuizamento estatal ou internacional, supón permitir ás e aos árbitros-xuíces un maior albedrío do que ás e aos xuíces estatais ou internacionais. Significa, polo tanto, menos garantías para as partes. Quizais, a única achega do borrador sexa a de suxeitar aos árbitros-xuíces a nomeamento previo e por períodos de 6 anos por parte dos EUA e a UE, así como unha maior garantía na súa predeterminación -é dicir, o nomeamento con carácter previo á apertura do preito- e o sometemento a un código ético (art. 11 Borrador) que tende a asegurar a independencia dos membros do tribunal, vetando a compatibilidade do cargo co de funcionarios ao servizo de calquera Estado, o sometemento a instrucións dadas por organizacións relacionadas co asunto en disputa e a posibilidade de actuar como asesores noutros casos sobre investimentos.

Agora ben, cómpre facer aquí unha referencia ao principio de independencia xudicial. A independencia refírese á configuración constitucional dun determinado órgano público,

\footnotetext{
${ }^{72}$ A declaración de resolución de controversias perante o TR Irán-EUA pode ser consultado aquí (Cfr. Especialmente o artigo III): http://www.iusct.net/General\%20Documents/2-Claims\%20Settlement\%20Declaration.pdf

${ }_{73}$ Dispoñíbel en http://trade.ec.europa.eu/doclib/docs/2015/september/tradoc_153807.pdf
} 
e implica impedir que o órgano independente estea sometido ás ordes doutros órganos de maior, menor ou igual rango. É un presuposto básico para a neutralidade da actuación institucional. Pero non o único.

No caso dos tribunais estatais tamén se predica a imparcialidade. Este principio está dirixido a garantir na medida do posíbel, que sempre é limitado, que a persoa con potestade xurisdicional poda verse inmersa en situacións que podan condicionar o seu prudente distanciamento fronte a calquera das partes. Por exemplo, na lexislación española recóllese a imposibilidade de que xuíces e maxistrados sexan membros nin de partidos políticos, nin de sindicatos, ou que leven ao cabo tarefas comerciais e/ou profesionais, ou que teñan relacións de parentesco con algunha das partes ou sexan amigas ou inimigas dalgunha delas ou dos seus representantes e asesores, entre outras.

A falta de imparcialidade segue sendo a gran eiva do procedemento. En efecto, tanto os membros do Tribunal de Investimentos (art. 9.4 Borrador) como os do Tribunal de Apelación (art. 10.7 Borrador), deben ser ou ben xuíces estatais, ou ben xuristas de recoñecida competencia, con experiencia en Dereito internacional -cousa dificilmente esixíbel a un xuíz estatal encargado, loxicamente, de aplicar a lei estatal, co cal se complica, de facto, esta posibilidade-, sendo especialmente desexábel, sempre segundo o borrador, que estes árbitros-xuíces teñan experiencia en Dereito internacional de investimentos e en Dereito comercial internacional. É preciso repetir neste punto que os dogmas desas parcelas do Dereito son antitéticos aos principios xerais da soberanía estatal, presuposto ineludíbel do Estado de Dereito e, con elo, da democracia liberal que, polo menos de iure, segue vixente nos Estados parte do Tratado.

En calquera caso, o vicesecretario de Estado de Comercio dos EUA negaba a posibilidade de negociar o Tratado sen a inclusión da cláusula $\operatorname{ISDS}^{74}$, o que pode deixar todo o proxecto de reforma en papel mollado. Nos últimos meses, os informes sobre a décimo segunda ${ }^{75}$ e décimo terceira ${ }^{76}$ roldas de negociacións amosan certa converxencia entre as partes negociadoras do tratado, especialmente nos ámbitos da transparencia e da posibilidade das partes contratantes para establecer a interpretación do Tratado, entre outras cuestións, mais, en todo caso, semella que subsiste o escepticismo da delegación estadounidense fronte á proposta da Comisión.

\section{CONCLUSIÓNS}

- A protección xurídica dos investimentos na contorna da UE e nos EUA é garantista para os inversores estranxeiros e, ademais, a configuración dos órganos xudiciais, acorde cos presupostos do Estado de Dereito, realiza un balance bastante razoábel entre os intereses das sociedades no seu conxunto e os intereses dos inversores

\footnotetext{
${ }^{74}$ http://www.euractiv.com/sections/trade-society/us-rejects-eu-proposal-investment-court-insists\%20-onretaining-isds-314501

${ }^{75}$ Dispoñíbel en http://trade.ec.europa.eu/doclib/docs/2016/march/tradoc 154391.pdf

${ }^{76}$ Dispoñíbel en http://trade.ec.europa.eu/doclib/docs/2016/may/tradoc_154581.pdf
} 
- Pola súa banda, a arbitraxe ISDS non aporta garantías suficientes de imparcialidade e de transparencia. Ademais, este método de arbitraxe deixa ampla discrecionalidade ás e aos árbitros, o que rebaixa o estándar de seguridade xurídica, e a práctica amosa que este facto soe xogar en detrimento dos Estados. Alén de máis, o alto custo soe operar como mecanismo disuasorio para os Estados e a propia redacción de moitos TPPIs no atinxente á resolución de controversias permite ás grandes corporacións especular co plantexamento de demandas perante a xurisdición ordinaria ou perante a arbitraxe, co obxectivo de incrementar as súas indemnizacións

- A proposta realizada pola Comisión Europea, para salvar as críticas que se teñen vertido pola inclusión da arbitraxe ISDS no ATCI, é a dun Tribunal arbitral que, en suma ven a ter un aspecto formal distinto do dos tribunais ad hoc, pero cuxa configuración material é idéntica á do ISDS. Aínda que esa nova proposta mellora sensibelmente aspectos relacionados coa obxectividade dos xuícesárbitros, como se ten apuntado, antóllase, de igual xeito, unha solución innecesaria e ameazante para o principio de soberanía estatal

\section{BIBLIOGRAFÍA}

BILLIET, J.; International Investment Arbitration. A practical Handbook; Maklu; Amberes, 2016

CAPIEL, L.; «El principio Kompetenz-Kompetenz en España» en Revista del Club español de Arbitraje, núm. 8/2010

COMISIÓN EUROPEA, «Fact sheet on Investment Protection and Investor-to-State Dispute Settlement un EU Agreements», Bruxelas, 2014

COMISIÓN EUROPEA, «ISDS. Some facts and figures», Bruxelas, 2015

CROFT, C.; KEE, C. e WAINCYMER, J.; A guide to the UNCITRAL Arbitration Rules; Cambridge University Press, Cambridge

DÍEZ DE VELASCO, M.; Instituciones de Derecho internacional público, Ed. Tecnos, $17^{\mathrm{a}}$ ed., Madrid, 2009

DOLZER, R.; SCHREUER, C.; Principles of International Investment Law, Oxford, Oxford University Press, 2012

DUGAN, C.; WALLACE, D.; RUBINS, N. e S, ABAHI, B.; Investor-State Arbitration; Oxford University Press, Oxford, 2008

EBERHARDT, P; OLIVET, C.; Profiting from injustice, Corporate Europe Observatory/ Transnational Institute, Bruxelas/Amsterdam, 2012

FERNÁNDEZ MASIÁ, E.; Arbitraje en inversiones extranjeras: el procedimiento arbitral en el CIADI; Tirant Lo Blanch, Valencia, 2004 
FERNÁNDEZ MASIÁ, E.; Tribunales nacionales, arbitraje internacional y protección de inversiones extranjeras, Ed. Marcial Pons, Madrid, 2008

GEORGE, S.; Los usupardores, Ed. Icaria, Barcelona, 2015

GRANATO, L.; Protección del Inversor Extranjero en los Tratados Bilaterales de Inversión, Bos Aires, 2005

PARLAMENTO EUROPEO, (Comité de Comercio internacional); «Working Document in view of preparing the draft report omn Parliament's report on the negotiations for the TTIP», Bruxelas, 2015

SARMIENTO, D.; Poder Judicial e integración europea. La construcción de un modelo jurisdiccional para la Unión; Ed. Thomsom Civitas, Madrid, 2004

SCHWAB, K. (Ed.); The Global Competitivenes Report 2013-2014, World Economic Forum, Xenebra, 2015

VVAA; Government perspectives on investor-state dispute settlement: a progress report, OECD, Paris, 2012

VVAA.; Public statement on the international investment regime, Londres, 2010

VAN HARTEN, G.; Investment Treaty Arbitration and Public Law; Oxford University Press, Oxford, 2007 